Research Article

\title{
Antioxidant Activities of Methanol Extracts of Thirteen Cameroonian Antibacterial Dietary Plants
}

\author{
Doriane E. Djeussi $(\mathbb{D}),{ }^{1}$ Jaurès A. K. Noumedem $(\mathbb{D}),{ }^{1,2}$ Marius Mihasan $\left(\mathbb{D},{ }^{2}\right.$ \\ Jules-Roger Kuiate $\mathbb{D}^{3},{ }^{3}$ and Victor Kuete $\mathbb{D}^{3}$ \\ ${ }^{1}$ Department of Physiological Sciences and Biochemistry, Faculty of Medicine and Pharmaceutical Sciences, \\ University of Dschang, P.O. Box 96, Dschang, Cameroon \\ ${ }^{2}$ Department of Biochemistry and Molecular Biology, Faculty of Biology, University of Iasi, Iasi, Romania \\ ${ }^{3}$ Department of Biochemistry, Faculty of Science, University of Dschang, P.O. Box 67, Dschang, Cameroon
}

Correspondence should be addressed to Jaurès A. K. Noumedem; jauresnoume@gmail.com and Victor Kuete; kuetevictor@yahoo.fr

Received 12 September 2020; Revised 18 November 2020; Accepted 23 November 2020; Published 9 December 2020

Academic Editor: Pasquale Longo

Copyright (c) 2020 Doriane E. Djeussi et al. This is an open access article distributed under the Creative Commons Attribution License, which permits unrestricted use, distribution, and reproduction in any medium, provided the original work is properly cited.

\begin{abstract}
This study falls within the search for alternative solutions to problems related to diseases associated with oxidative stress. It involved the evaluation of antioxidant activities extracts from thirteen antibacterial Cameroonian food plants, namely, $P$. nigrum, A. cruentus, L. sativa, S. edule, S. nigrum, V. amygdalina, A. hybridus, V. hymenolepis, L. capensis, M. esculenta, C. melo, T. occidentalis, and T. triangulare. The thirteen plant extracts with a broad spectrum of antibacterial activity all showed total reducing powers ranging between 2.41 and $27.81 \mathrm{AAE}$ (mg ascorbic acid equivalents per gram of dried extract) and total phenol contents between 2.65 and $35.03 \mathrm{GAE}$ ( $\mathrm{mg}$ of gallic acid equivalents per gram of dried extract) of dry extract. Except for extracts of L. capensis, the other 12 extracts showed flavonoid contents ranging between 0.29 and $5.99 \mathrm{RE}$ (rutin equivalents per gram of dried extract). All 13 plant extracts also showed free radical scavenging activity against $\mathrm{DPPH} \cdot$ with $\mathrm{IC}_{50}$ ranging between 1.65 and $310.52 \mu \mathrm{g} / \mathrm{ml}$, while 12 of these extracts exhibited inhibitory activity against NO radical ( IC $_{50}$ ranging from 19.77 to $157.72 \mu \mathrm{g} / \mathrm{ml}$ ). Statistically insignificant positive correlations $(p>0.5)$ were found between antibacterial activities of these plants and their antioxidant activities. The different results of this study provide scientific evidence for the use of these antibacterial food plants in the control of different conditions associated with oxidative stress.
\end{abstract}

\section{Introduction}

Oxidative stress is a condition which arises when reactive oxygen species (ROS) production becomes higher than antioxidant defense of the organism. If antioxidant capacities of the organism decrease or there is an increase in ROS production, the systemic antioxidant/oxidative dysfunction can lead to the accumulation of oxidative damage, which in turn can lead to modification of biomolecules with the occurrence of reactions that lead to protein additions, DNA oxidation, and lipid peroxidation with cellular functional ability reduction and risk of disease increase. Reactive oxygen species (ROS) and reactive nitrogen species (RNS) levels can be generated through signal transduction pathways and regulation of physiological events such as cell cycle, programmed cell death, and inflammation [1]. It has been established that infectious diseases trigger the production of ROS and RNS which are at the origin of an increase of susceptibility to secondary infections via a mechanism of tissue injury as well as impairment of epithelial barrier functions [2].

The body contains natural cleansing systems against free radicals and other reactive species. However, ROS production sometimes exceeds internal antioxidant capacity leading to oxidative stress. Therefore, external antioxidants have an important function in human health. These 
bioactive compounds act preventively and neutralize the formation of new reactive species and free radicals. The exogenous antioxidants are mainly derived from food and medicinal plants including fruits, vegetables, and spices which in recent years gained great interest in their antioxidant activity. These plants contain natural antioxidants mainly made of phenolic compounds. Phenolic compounds include phenolic acids, polyphenols, and flavonoids that protect plants, fruits, and vegetables from oxidative damage [3].

In two previous research papers, we highlighted antibacterial activities of the thirteen Cameroonian antibacterial plants used in this study, namely, Piper nigrum, Amaranthus cruentus, Lactuca sativa, Sechium edule, Solanum nigrum, Vernonia amygdalina, Amaranthus hybridus, Vernonia hymenolepis, Lactuca capensis, Manihot esculenta, Cucurbita melo, Telfairia occidentalis, and the fruits of Piper nigrum $[4,5]$. These edible plants are used for many purposes in African traditional medicine (Table 1). In our previous studies, we demonstrated that the methanol extracts of these 13 plants inhibit the growth of Gram-negative multidrug-resistant bacteria with MIC values ranging between 32 and $1024 \mu \mathrm{g} / \mathrm{ml}$ and can then be used in the control of bacterial infections including MDR phenotypes $[4,5]$. The present study aims to determine the contents in total phenols and total flavonoids and antioxidant activities of methanol extracts of thirteen plants.

\section{Material and Methods}

2.1. Plant Extract Preparation. In June 2010, thirteen edible Cameroonian edible plants were harvested in Cameroon, West Region, City of Dschang. The collected plant materials were the fruits of P. nigrum, A. cruentus, L. sativa, S. edule, $S$. nigrum, $V$. amygdalina, A. hybridus, $V$. hymenolepis, L. capensis, M. esculenta, C. melo, T. occidentalis, and the fruits of $P$. nigrum. The plants were further identified and authenticated at the National Herbarium of Cameroon under voucher specimen numbers (see Table 1).

Each sample was air-dried at room temperature (RT), and the resulting powder was extracted for $48 \mathrm{~h}$ at RT using methanol as solvent. Afterward, the extracts were filtered using Whatman No.1 paper and the crude extracts were obtained after reduced pressure concentration.

2.2. Determination of Total Reducing Power. The total reducing power of plant extracts was determined as previously described with some modifications. Briefly, the reaction mixture was prepared in phosphate buffer sodium (PBS) $(0.2 \mathrm{M}, \mathrm{pH} 6.6)$ with $100 \mu \mathrm{g} / \mathrm{ml}$ of each extract, $440 \mu \mathrm{L}$ of potassium ferrocyanide $\left(\left[\mathrm{K}_{3} \mathrm{Fe}(\mathrm{CN})_{6}\right] 1 \%\right)$, and $440 \mu \mathrm{L}$ of $10 \%$ trichloroacetic acid. The samples were then centrifuged for $10 \mathrm{~min}$ at $3000 \mathrm{rpm}$, and $680 \mu \mathrm{L}$ of supernatant from each tube was collected and introduced into a new tube containing $\mathrm{FeCl}_{3}(140 \mu \mathrm{L})$ and demineralized water $(680 \mu \mathrm{L})$. The absorbance of these new solutions was read at $700 \mathrm{~nm}$ and converted into milligrams of ascorbic acid equivalents
(AAE) per gram of dried extract using a calibration curve (prepared using different concentrations of ascorbic acid used in the same manner as extracts).

2.3. Determination of Total Phenol Content. The determination of total phenol content of plant extracts was carried out using the Folin-Ciocalteu technique [98]. Briefly, a stock solution of Folin-Ciocalteu reagent was diluted 10 times. Then $500 \mu \mathrm{L}$ of this solution was added to $100 \mu \mathrm{L}$ of extract $(10 \mathrm{mg} / \mathrm{ml})$ dissolved in 10\% DMSO. After $4 \mathrm{~min}$ of incubation at room temperature (RT), $400 \mu \mathrm{L}$ of $7.5 \%$ of $\mathrm{Na}_{2} \mathrm{CO}_{3}$ solution was added to the mixture and the absorbance of the final solution was read at $765 \mathrm{~nm}$. The absorbance was further converted into milligrams of gallic acid equivalents (GAE) per gram of dried extract using a calibration curve prepared using different concentrations of gallic acid (Figure 1) used in the same manner as extracts.

2.4. Determination of Total Flavonoid Contents. The determination of total flavonoid content of each plant extract was carried out using the spectrophotometric method of aluminum chloride $\left(\mathrm{AlCl}_{3}\right)$ using rutin (Figure 1) as a standard flavonoid. Briefly, $100 \mu \mathrm{L}$ of each plant extract $(10 \mathrm{mg} / \mathrm{ml})$ was mixed with $400 \mu \mathrm{L}$ of $\mathrm{MeOH}, 20 \mu \mathrm{L}$ of $\mathrm{AlCl}_{3} 10 \%, 20 \mu \mathrm{L}$ of acetic acid $\left(\mathrm{CH}_{3} \mathrm{COOK}, 1 \mathrm{M}\right)$, and $560 \mu \mathrm{L}$ of distilled water. The reaction mixture was then incubated for $4 \mathrm{~min}$ at RT. After the incubation period, the absorbance was measured at $415 \mathrm{~nm}$ and converted into micrograms of rutin equivalents (RE) per gram of dried extract using a calibration curve (OD vs. rutin concentration).

\subsection{Evaluation of the DPPH Radical Scavenging Activity of} Plant Extracts. Radical scavenging activity of plant extracts was evaluated as described in a previous study [99]. $100 \mu \mathrm{L}$ of each plant extract (dissolved in methanol) was added to $900 \mu \mathrm{L}$ of DPPH (20 mg/l dissolved in methanol), to obtain concentrations of $32,64,128,256$, and $512 \mu \mathrm{g} / \mathrm{ml}$. Positive control was made up of L-ascorbic acid (Figure 1) while $1 \mathrm{~mL}$ of DPPH $(20 \mathrm{mg} / \mathrm{L}$ in methanol) served as the negative control. The incubation was made for $30 \mathrm{~min}$ at RT in a dark cupboard after mixture. The absorbance was measured at $517 \mathrm{~nm}$ and converted into percentage of scavenging activity using the following equation:

$$
\% \text { RSA }=\frac{\text { absorbance of DPPH }- \text { absorbance of test sample }}{\text { absorbance of DPPH }} \times 100 \text {. }
$$

Probit table was then used to convert \%RSA into probits which were plotted against the logarithmic values of the concentrations, and a linear regression curve was established to calculate the $\mathrm{RSa}_{50}$ defined as the quantity of each plant extract which decreases by $50 \%$ the free radical DPPH. A comparison was made between percentages of DPPH scavenged by test samples and percentages of DPPH scavenged by L-ascorbic acid (using the results of triplicate experiments). 
TABLE 1: Evidence of the activities of the methanol extracts of thirteen antibacterial edible plants.

\begin{tabular}{lllll}
\hline $\begin{array}{l}\text { Plant (family); voucher } \\
\text { numbers }\end{array}$ & Traditional uses & $\begin{array}{c}\text { Parts } \\
\text { used }\end{array}$ & $\begin{array}{c}\text { Bioactive or potentially } \\
\text { bioactive components }\end{array}$ & $\begin{array}{c}\text { Bioactivities of extracts and/or } \\
\text { compounds }\end{array}$ \\
\hline
\end{tabular}

Flavonoids, steroids, terpenoids,

cardiac glycosides [6], alkaloid,

Amaranthus hybridus Intestinal bleeding, diarrhoea,

Linn (Amaranthaceae); and excessive menstruation

$15630 \mathrm{HNC}$
Leaves,

seeds saponin, tannins, phenols,

hydrocyanic acid, and phytic acid $[8,9]$

Vernonia hymenolepis

(H.F.) Hook

(Asteraceae); 42401/

HNC
Wounds [11], anticancer [12], fever, stomach ache, diarrhoea, hernia, spleen enlargement [13]
Vernolepin [14, 15],

Leaves vernomenin [15], flavonoids (quercetin, apigenin, and luteolin) [16]
Antimicrobial $[4,6,10]$

Cytotoxic [14], spasmolytic, antiaggregating and

deaggregating activities, antitumor activity, antimicrobial [17], insecticide [18], antifilarial [19]

Phenolic acids, triterpenoids, saponins, phytol [20],

Analgesic, conjunctivitis, tired eyes, insomnia, sedative insomnia [20], anxiety, neurosis, dry coughs,

Lactuca sativa Linn (Asteraceae); 25624/ SRF.Cam

rheumatic pain [21], stimulate digestion, enhance appetite, and relieve inflammation [22] carotenoids [23], flavonoids including kaempferol [16], Leaves lettucenin-A guaianolide sesquiterpene lactones conjugates, lactucin, deoxylactucin, and lactucopicrin [24]
Antimicrobial [4, 25], antifungal, antibacterial [26], antitumor [27] antioxidating, analgesic, and antiinflammatory [20], depressant

[28] sedative, hypnotic, analgesic, and anticonvulsant [29], hypoglycaemic [30], antioxidant 1 $[31,32]$, and anxiolytic

Antispasmodic, digestive, diuretic, hypnotic, narcotic, and sedative properties. Treatment of insomnia, anxiety, neuroses,

Lactuca capensis Thumb (Asteraceae); 27743 HNC

hyperactivity in children, dry Leaves

Lactucarium, sesquiterpene lactone [34]
Antibacterial against Gramnegative multidrug-resistant bacteria [4] coughs, whooping cough,

rheumatic pain, chronic join pains [33]

Sechium edule (Jacq) SW (Cucurbitaceae); 42459/HNC

Urine retention, kidney diseases, arteriosclerosis, hypertension [35]
C-glycosyl and O-glycosyl, flavones in roots, leaves, stem, Leaves and fruits [36], ascorbic acid, gibberellins, flavonoids, and saponins [35]

Diuretic [37], free radical scavenger and antioxidant [38], antibacterial [4, 39], antihypertensive [40], hepatoprotective activity of ethanolic extract, and its different fractions [41]

3-Rutinosides of kaempferol and quercetin; the cyanogenic

Manihot esculenta

Crantz

(Euphorbiaceae); 57650/HNC

\author{
Hypertension, headache and \\ pain, irritable bowel \\ syndrome, fever, headache, \\ aches, and pains [42]
}

\section{Leaves} glycosides, lotaustralin, and linamarin, from the fresh leaves of cassava [43]
Cucurbita pepo Linn (Cucurbitaceae); 15630 HNC
Intestinal infections and kidney problems (seeds), minor injuries (flowers), anthelmintic, hypertension, erysipelas, enteritis, dyspepsia, stomach disorders, liver disorders like jaundice [45]
Saponin, tannin, quinone, coumarins, flavonoids, sterol, terpenes, [46] lignin, alkaloids, protein, and sugar curbicin [47] anthocyanin, phenols like syringic acid [47], phytin, lecithin, cucurbitane, and hexanocucurbitane L-2-O$\beta$-glucopyranoside, curbicin

[47], flavonoids, vitamins B, C, and $\mathrm{E}, \beta$-sitosterol
Anthelmintic activity of crude extracts antibacterial $[4,44]$

Antihypertensive, antioxidative activities, arthritis, reduce the symptoms of BPH $[47,48]$. High cholesterol, antiparasitic activity in vitro [49], alleviates the detrimental effects associated with protein malnutrition [50], antiparasitic [51], nephron, and hepatoprotective, vermifuge, inhibitor of prostaglandin biosynthesis [52], antiparasitic, protects gastric mucosal [45], antibacterial against Gramnegative multidrug-resistant bacteria [4] 
TABle 1: Continued.

\begin{tabular}{|c|c|}
\hline $\begin{array}{l}\text { Solanum nigrum Linn } \\
\text { (Solanaceae); } 43000 \\
\text { HNC }\end{array}$ & $\begin{array}{l}\text { Pneumonia aching teeth, } \\
\text { stomach ache, tonsillitis, tonic, } \\
\text { wing worms [11], pain, } \\
\text { inflammation, and fever. } \\
\text { Tumor, antioxidant, anti- } \\
\text { inflammatory, } \\
\text { hepatoprotective, diuretic, } \\
\text { antipyretic [53] }\end{array}$ \\
\hline
\end{tabular}

K

Kaempferol [16, 54], terpenoids and condensed tannin [55], quercetin, flavonoids [16],

Leaves polysaccharides, polyphenolic compounds including gallic acid, catechin, caffeic acid, rutin, and naringenin [53]

Anti-inflammatory, antioxidant, anthelmintic activity [55] antinociceptive, antipyretic, antitumor, antiulcerogenic, cancer chemopreventive, hepatoprotective, and immunomodulatory effects [56] mosquito larvicidal [57], antibacterial $[4,58]$

Antiapoptotic [63, 64], antibacterial and antibiotic potentiation $[5,59,65]$, antidepressant [66], antifungal

[67], analgesic, anti-inflammatory [68], antidiarrhoeal [69], antimutagenic, antioxidative,

Cardiovascular diseases, $\begin{array}{ll}\text { Piper nigrum } & \text { intoxication, inflammation, } \\ \text { L. (Piperaceae); 25818/ } & \text { bacterial, fungal, and parasitic }\end{array}$ SFRcam infections, respiratory diseases, asthma [59]
Piperine, pipene [60], Seeds piperamides, piperamine [61], pellitorine [62] increase plasma [70], antipyretic [68], immunomodulatory, antispasmodic [71, 72], asthma, obesity, sinus antispermatogenic, antithyroid, antitumor ciprofloxacin potentiator, transcription inhibitor, insecticidal, hepatoprotective, increase pancreatic enzymes, cytochrome inhibitor [59]

Microbial infections [73], hiccups, kidney problems and stomach discomfort [74], stomach ache and Vernonia amygdalina Del. (Asteraceae ); 31149/SRFK gastrointestinal pain, malarial fever, cough remedy [75], Leaves antimalaria, purgative, antiparasitic, eczema blood glucose levels control [76], treatment of eczema [76]
Active anticancer [78], antimalarial and antiparasitic agents [79], hypoglycaemic [80], antimicrobial, antibacterial and antibiotic potentiation [5], alkaloids [75], vernodalin vernomygdin, vernonioside $\mathrm{B} 1$, and vernoniol B1 [77]

antihelminthic, antischistosomal, tumor inhibitor [77], hypolipidaemic and antioxidant properties [81]

Antimicrobial and antibiotic potentiation [5], antioxidant and

Telfairia occidentalis (Cucurbitaceae); 33423/HNC
Microbial infections, cholesterolemia, liver problems, and impaired defense immune systems [82]
Leaves Phenols, alkaloids, and tannins [83] free radical scavenger [83, 84], antiplasmodial, cure lactating properties, hypoglycemic and antidiabetic [82]

Antioxidant [91] and Against infectious diseases, Leaves Essential oil, alpha-tocopherols, burns [85], internal heat, and beta-tocopherols [88], alkaloids, cramps, IST [86], (Jacq.) Willd. (Portulacaceae); 11537 SRFcam cardiovascular diseases [87]

entire flavonoids, saponins, tannins plants [89], $\beta$-carotene, minerals [90]

neuroprotective [92], hemolytic and hyperglycemic [86], prooxidant [93], antiinflammatory [94], tonic [95]

Antioxidant against lipid Phenols, anthocyanins [96],

Amaranthus cruentus

Linn (Amaranthaceae); $42335 \mathrm{HNC}$
Leaves and seeds carbonic anhydrases [97],

$\alpha$-tocopherols, oleic acids,

linoleic and folic acids, riboflavin and niacin peroxidation, DPPH and ABTS

radicals [96], antibacterial against

Gram-negative multidrugresistant bacteria [4]

${ }^{a}$ HNC: Cameroon National Herbarium; SRFC: Société des Réserves Forestières du Cameroun.

2.6. Assessment of Nitric Oxide Complexation Radical. At physiological $\mathrm{pH}$, sodium nitroprusside decomposes itself in solution with the production of $\mathrm{NO}$ - free radicals. In aerobic conditions, NO radicals lead to the formation of nitrites. The chromogen formed during diazotization with nitrite ions with Griess reagent has a maximum absorbance at a wavelength of $546 \mathrm{~nm}$ [100].
In this study, the nitric oxide was generated from sodium, and nitroprusside was measured using modified Griess reagent. For instance, $1 \mathrm{ml}$ of a solution of sodium nitroprusside dissolved in phosphate buffer (phosphatebuffered saline or PBS) was added to each test tube and mixed with $100 \mu \mathrm{L}$ of solutions of extracts to obtain different concentrations $(4,16,64,256$, and $1024 \mu \mathrm{g} / \mathrm{ml})$. The mixture 
<smiles>O=C1O[C@H]([C@@H](O)CO)C(O)=C1O</smiles>

(a)<smiles>O=C(O)c1cc(O)c(O)c(O)c1</smiles>

(b)

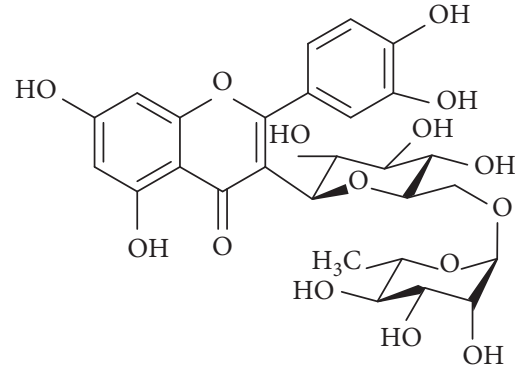

(c)

FIGURE 1: Structural formula of some molecules with antioxidant properties used as reference antioxidants. (a) Ascorbic acid. (b) Gallic acid. (c) Rutin.

was then incubated at RT for $180 \mathrm{~min}$. After incubation, $100 \mu \mathrm{L}$ of modified Griess reagent was added to each tube. Then, the absorbance was monitored at $540 \mathrm{~nm}$ and converted into percentage of radical scavenging activity (\%RSA) using the following equation:

$$
\% \text { RSA }=\frac{\text { absorbance of control }- \text { absorbance of test sample }}{\text { absorbance of control }} \times 100 \text {. }
$$

The probit table was then used to convert \%RSA into probits which were plotted against the logarithmic values of the concentrations, and a linear regression curve was established to calculate the $\mathrm{RSa}_{50}$, which are the amounts of sample necessary to decrease by $50 \%$ the free radical NO. The experiment was carried out in triplicate and the percentages of NO scavenged by test samples were compared to that of rutin.

2.7. Statistical Analysis. Statistical Package for Social Science (SPSS, version 18.0) was used to carry out statistical analysis. Data from each experience were expressed as mean\pm standard deviation (SD). One-way analysis of variance (ANOVA) followed by the Waller-Duncan post hoc test was used for group comparisons. Differences were considered significant at a $p$ value $\geq 0.05$.

\section{Results}

The antioxidant properties of extracts were assessed using five different methods. These experiments allowed the obtention of variable results according to the extracts and tests used.

Compared to the total reducing power and content of total phenols, $P$. nigrum stood out clearly with the largest respective values of $30.12 \mathrm{AAE}$ (Table 2) and 14.01 GAE (Table 3), while the other 12 extracts showed reducing power between 1.62 and 8.41 AAE (Table 2), and total phenols comprised between 2.34 and 7.71 GAE (Table 3 ) and a strong correlation was also observed between the results of these two methods with a coefficient of correlation of 0.868 (Table 4), reflecting the strong involvement of phenols in the reducing power of the extracts of this study. However, higher levels of flavonoids were not obtained with extracts showing the greatest levels of total phenols. Actually, among the 4 extracts
TABLE 2: Total reducing power of the methanol extracts of thirteen antibacterial edible plants.

\begin{tabular}{|c|c|}
\hline Plant extracts & Total reducing power $(\mathrm{AAE})^{*}$ \\
\hline Amaranthus hybridus & $1.62 \pm 0.12^{\mathrm{g}}$ \\
\hline Amaranthus cruentus & $3.21 \pm 0.49^{f}$ \\
\hline Cucumis melo & $8.41 \pm 0.60^{b}$ \\
\hline Lactuca capensis & $2.83 \pm 0.04^{\mathrm{f}}$ \\
\hline Lactuca sativa & $6.37 \pm 0.54^{\mathrm{d}}$ \\
\hline Manihot esculenta & $8.22 \pm 0.40^{b c}$ \\
\hline Piper nigrum & $30.13 \pm 0.92^{\mathrm{a}}$ \\
\hline Sechium edule & $4.87 \pm 0.15^{\mathrm{e}}$ \\
\hline Solanum nigrum & $3.37 \pm 0.71^{\mathrm{f}}$ \\
\hline Talinum triangulare & $3.31 \pm 0.43^{\mathrm{f}}$ \\
\hline Telfairia occidentalis & $4.54 \pm 0.23^{\mathrm{e}}$ \\
\hline Vernonia hymenolepis & $5.98 \pm 0.11^{\mathrm{d}}$ \\
\hline Vernonia amygdalina & $7.44 \pm 0.36^{c}$ \\
\hline
\end{tabular}

${ }^{*} \mathrm{AAE}: \mu \mathrm{g}$ of ascorbic acid equivalents per gram of dried extract.

TABLE 3: Total phenol content of the methanol extracts of thirteen antibacterial edible plants.

\begin{tabular}{lc}
\hline Plant extracts & Total phenols content $(\mathrm{GAE})^{*}$ \\
\hline Amaranthus hybridus & $\mathbf{7 . 3 1} \pm \mathbf{0 . 2 2} \mathbf{2}^{\mathbf{b c}}$ \\
Amaranthus cruentus & $1.23 \pm 0.25^{\mathrm{g}}$ \\
Cucumis melo & $\mathbf{7 . 7 1} \pm \mathbf{0 . 0 3}$ \\
Lactuca capensis & $5.62 \pm 0.22^{\mathrm{d}}$ \\
Lactuca sativa & $\mathbf{6 . 8 2} \pm \mathbf{0 . 2 7 ^ { \mathrm { c } }}$ \\
Manihot esculenta & $4.93 \pm 0.13^{\mathrm{d}}$ \\
Piper nigrum & $\mathbf{1 4 . 0 1} \pm \mathbf{0 . 1 0 ^ { \mathbf { a } }}$ \\
Sechium edule & $2.58 \pm 0.32^{\mathrm{f}}$ \\
Solanum nigrum & $2.98 \pm 0.08^{\mathrm{ef}}$ \\
Talinum triangulare & $3.51 \pm 0.44^{\mathrm{e}}$ \\
Telfairia occidentalis & $2.65 \pm 0.03^{\mathrm{ef}}$ \\
Vernonia hymenolepis & $3.12 \pm 0.21^{\mathrm{ef}}$ \\
Vernonia amygdalina & $2.34 \pm 0.31^{\mathrm{f}}$ \\
\hline
\end{tabular}

${ }^{*}$ GAE: mg of gallic acid equivalents per gram of dried extract.

showing the highest flavonoid content (Table 5), we noticed the presence of $M$. esculenta (the only one of the 4 extracts with one of the highest phenolic contents) and especially that of $A$. cruentus which showed the lowest phenolic content. This lack of correlation between flavonoid contents and phenolic contents and between flavonoid content and total reducing power of the extracts on the other hand was further confirmed through correlation factors (Table 4). 
TABLE 4: Total flavonoid content of the methanol extracts of thirteen antibacterial edible plants.

\begin{tabular}{lc}
\hline Plant extracts & Total flavonoids content $\left(\mathrm{RE}^{*}\right)$ \\
\hline Amaranthus hybridus & $1.91 \pm 0.32^{\mathrm{e}}$ \\
Amaranthus cruentus & $5.59 \pm 0.27^{\mathrm{a}}$ \\
Cucumis melo & $4.50 \pm 0.27^{\mathrm{ab}}$ \\
Lactuca capensis & $0.00 \pm 0.00^{\mathrm{f}}$ \\
Lactuca sativa & $5.59 \pm 0.50^{\mathrm{a}}$ \\
Manihot esculenta & $5.99 \pm 0.53^{\mathrm{a}}$ \\
Piper nigrum & $3.88 \pm 0.10^{\mathrm{b}}$ \\
Sechium edule & $3.78 \pm 0.41^{\mathrm{bc}}$ \\
Solanum nigrum & $1.80 \pm 0.23^{\mathrm{de}}$ \\
Talinum triangulare & $5.50 \pm 0.58^{\mathrm{a}}$ \\
Telfairia occidentalis & $0.29 \pm 0.03^{\mathrm{ef}}$ \\
Vernonia hymenolepis & $1.02 \pm 0.22^{\mathrm{de}}$ \\
Vernonia amygdalina & $2.27 \pm 0.02^{\mathrm{cd}}$ \\
\hline
\end{tabular}

${ }^{*} \mathrm{RE}: \mu \mathrm{g}$ of rutin equivalents per gram of dried extract.

Correlation analysis was also made between the antibacterial activities of extracts (Supplementary data available here) and the antioxidant activities obtained with each of the five methods used in this work. The results presented in the last row of Table 4 showed that there are statistically insignificant positive correlations $(p>0.5)$ between the antibacterial activities of these plants and the antioxidant activities obtained with each of the five methods. The strongest correlation was observed between antibacterial activities and total phenols content, followed by free radical scavenging activity against nitric oxide. The weakest correlation was observed between antibacterial activities and total flavonoid content, followed by free radical scavenging activity against $\mathrm{DPPH}$ and total reducing power. This correlation analysis could suggest that although the correlation between the antibacterial and the antioxidant activities of the extracts in this study is not very high, the phenols they contain may exert both antibacterial and antioxidant activities.

The radical scavenging activities of extracts expressed here as $\mathrm{RSa}_{50}$ varied according to radicals and extracts. Thus, with the NO radical, the greatest activity was observed with A. hybridus $\left(\mathrm{RSa}_{50}=19.77 \mu \mathrm{g} / \mathrm{ml}\right)$, greater than that of rutin used as reference antioxidant $\left(\mathrm{RSa}_{50}=157.72 \mathrm{~g} / \mathrm{ml}\right)$. Four other extracts ( $T$. occidentalis, V. amygdalina, L. capensis, and M. esculenta) also showed activities higher than that of rutin. Extracts of $V$. hymenolepis and $S$. nigrum exhibited free radical scavenging activity statistically similar to that of rutin. The remaining six samples exhibited activities, which, although significantly lower than that of rutin, is still important in most cases (Table 6).

Against the DPPH free radical, all the 13 extracts exerted scavenging activities with $\mathrm{RSa}_{50}$ ranging from 1.65 (P. nigrum) to $109.22 \mathrm{mg} / \mathrm{ml}$ (C. melo). Apart from the extract of $P$. nigrum which showed best radical scavenging activities against DPPH', seven other extracts showed $\mathrm{RSa}_{50}$ values which were lower than $50 \mathrm{mg} / \mathrm{ml}$. These extracts include S. edule, M. esculenta, L. capensis, V. hymenolepis, A. cruentus, and V. amygdalina (Table 7).

Negative correlation was observed between free radical scavenging activity of extracts against $\mathrm{NO}$ and phenol contents, while there were insignificant correlations between scavenging activity, reducing power, and total flavonoid content, suggesting that these elements do not play a significant role in the trapping of NO. A significant correlation was observed between the scavenging activity vis-à-vis the $\mathrm{DPPH}$ and total reducing power, showing that these two activities are linked to the same compounds, while nonsignificant correlations were observed between DPPH and the contents of flavonoids and total phenols.

Antioxidant activities undertaken in this study corroborate the results of other studies that reported the benefits of fruits and vegetables and give information about the subject. Fruits and vegetables are known for their ability to protect organisms through antioxidant properties. They are very rich in antioxidants, and several publications were already made on different plants of this study (Table 1). Some highlights concern the wealth of some of these fruits and vegetables antioxidant reference such as vitamin $\mathrm{C}$, vitamin $\mathrm{E}$, and quercetin in A. hybridus, M. esculenta, P. vulgaris, and S. nigrum (Table 1 ).

Previous studies showed the plants of the genus Amaranthus used in this study, namely, A. hybridus and A. cruentus presented phenols in varying degrees depending on the extraction solvent [101]. Without determining the $\mathrm{RSa}_{50}$, the same study showed that A. cruentus and A. hybridus exerted antiradical activity against different radicals including $\mathrm{NO}^{\circ}$. Moreover, it has been proven that the extract of $A$. cruentus helps to fight against oxidative stress in rats by increasing the activity of different antioxidant enzymes of plasma [102].

A study has shown that the ethanolic, aqueous, and acetone extracts pomace of roots of $B$. vulgaris contains phenols (316.30 to $564.50 \mathrm{GAE}$ ) and flavonoids (200.50 to 253.50 RE) [103]. Much higher levels than those of the methanolic extract of the whole root were found in this study (9.28 GAE and 0.25 RE, respectively, for phenols and flavonoids). However, with an $\mathrm{RSa}_{50}$ of $175.49 \mu \mathrm{g} / \mathrm{ml}$, the extract presented an antiradical activity against $\mathrm{DPPH}^{\circ}$ comparable to the one found in a previous study $\left(\mathrm{RSa}_{50}\right.$ between 133 and $275 \mathrm{mg} / \mathrm{ml}$ ) [103]. It was also demonstrated that the methanol extract inhibits lipid peroxidation, preserves the activity of plasma antioxidant enzymes, and prevents excessive fluidity of plasma membranes in rats that received $\mathrm{CCl}_{4}$ [104].

It was previously shown that $C$. melo may be used as a source of natural antioxidant due to its contents in phenols of $26.4 \pm 0.3 \mathrm{GAE}$ and flavonoids of $69.7 \pm 3.37 \mathrm{RE}$ [105]. It is also capable of reducing the production of superoxide, nitrite, and peroxynitrite. These antioxidant activities would be partly explained by its richness in antioxidants such as glutathione, carotenoids, or vitamin E [106]. C. pepo also contains phenols including flavonoids and a scavenging activity against $\mathrm{DPPH}^{\circ}$ variables with content specifically fertilizer and soil composition in general [107].

It was also reported that ethanol extracts of leaves and seeds of aqueous extracts of $S$. edule possess antioxidant activities performed through the inhibition of lipid peroxidation, the activity of free radical scavenging against the $\beta$-carotene and $\mathrm{DPPH}^{\circ}$, with an $\mathrm{RSa}_{50}$ of $2 \mathrm{mg} / \mathrm{ml}$. These previous studies showed that the aqueous and ethanolic 
TABLE 5: DPPH radical scavenging activities of the methanol extracts of thirteen antibacterial edible plants.

Plant extracts

Amaranthus hybridus

Amaranthus cruentus

Cucumis melo

Lactuca capensis

Lactuca sativa

Manihot esculenta

Piper nigrum

Sechium edule

Solanum nigrum

Talinum triangulare

Telfairia occidentalis

Vernonia hymenolepis

Vernonia amygdalina

L-ascorbic acid

Radical scavenging activities expressed as $\mathrm{RSa}_{50}(\mu \mathrm{g} / \mathrm{ml})$

$$
\begin{gathered}
310.52 \pm 41.19^{\mathrm{g}} \\
38.48 \pm 3.03^{\mathrm{bcd}} \\
109.22 \pm 10.04^{\mathrm{e}} \\
\mathbf{1 9 . 4 4} \pm \mathbf{0 . 9 9} \mathbf{\mathbf { a b c }} \\
163.21 \pm 10.09^{\mathrm{f}} \\
\mathbf{1 6 . 2 2} \pm \mathbf{0 . 5 1}^{\mathbf{a b}} \\
\mathbf{1 . 6 5} \pm \mathbf{0 . 1 6}^{\mathbf{a}} \\
\mathbf{1 1 . 3 9} \pm \mathbf{0 . 2 6}^{\mathbf{a b}} \\
48.89 \pm 5.66^{\mathrm{cd}} \\
64.34 \pm 4.39^{\mathrm{d}} \\
48.23 \pm 2.93^{\mathrm{cd}} \\
\mathbf{3 8 . 4 8} \pm \mathbf{7 . 2 8} \\
\mathbf{2 4 . 9 1} \pm \mathbf{2 . 2 3}^{\mathbf{b b c}} \\
\mathbf{1 . 8 6} \pm \mathbf{0 . 1 0}^{\mathbf{a}}
\end{gathered}
$$

\begin{tabular}{|c|c|c|c|c|c|}
\hline & $\begin{array}{c}\text { Total reducing } \\
\text { power }\end{array}$ & $\begin{array}{l}\text { Total flavonoids } \\
\text { content }\end{array}$ & $\begin{array}{c}\text { Total phenols } \\
\text { content }\end{array}$ & $\begin{array}{l}\text { NO· radical scavenging } \\
\text { activity }\end{array}$ & $\begin{array}{c}\text { DPPH' radical scavenging } \\
\text { activity }\end{array}$ \\
\hline \multicolumn{6}{|l|}{ Total reducing power } \\
\hline Total flavonoid content & $\begin{array}{l}0.449 * * \\
(0.0003)\end{array}$ & & & & \\
\hline Total phenol content & $0.263 *(0.015)$ & $0.114(0.292)$ & & & \\
\hline $\begin{array}{l}\text { NO } \text { radical scavenging } \\
\text { activity }\end{array}$ & $0.254 *(0.018)$ & $0.273 *(0.011)$ & $-0.138(0.2)$ & & \\
\hline $\begin{array}{l}\mathrm{DPPH} \cdot \text { radical scavenging } \\
\text { activity }\end{array}$ & $0.362 *(0.01)$ & $0.125(0.246)$ & $0.095(0.379)$ & $-0.114(0.288)$ & \\
\hline Antibacterial activity & $0.116(0.483)$ & $0.077(0640)$ & $0.236(0.148)$ & $0.225(0.169)$ & $0.113(0.495)$ \\
\hline
\end{tabular}

$\mathrm{RSa}_{50}$ : concentration of tested sample necessary to decrease by $50 \%$ the free radical DPPH. Values bearing the different superscript letters are significantly different $(p<0.05)$.

TABLE 6: NO radical scavenging activities of the methanol extracts of thirteen antibacterial edible plants.

\begin{tabular}{lc}
\hline Plant extracts & Radical scavenging activities expressed as $\mathrm{RSa}{ }_{50}(\mu \mathrm{g} / \mathrm{ml})$ \\
\hline Amaranthus hybridus & $760.25 \pm 65.02^{\mathrm{f}}$ \\
Amaranthus cruentus & $524.13 \pm 37.30^{\mathrm{e}}$ \\
Cucumis melo & $58.38 \pm 3.27^{\mathrm{a}}$ \\
Lactuca capensis & $74.58 \pm 3.82^{\mathrm{ab}}$ \\
Lactuca sativa & $19.77 \pm 1.80^{\mathrm{a}}$ \\
Manihot esculenta & $118.60 \pm 6.60^{\mathrm{abc}}$ \\
Piper nigrum & $477.09 \pm 19.32^{\mathrm{e}}$ \\
Sechium edule & $738.77 \pm 35.49^{\mathrm{f}}$ \\
Solanum nigrum & $233.27 \pm 7.26^{\mathrm{d}}$ \\
Talinum triangulare & - \\
Telfairia occidentalis & $53.05 \pm 2.06^{\mathrm{a}}$ \\
Vernonia hymenolepis & $191.97 \pm 20.85^{\mathrm{cd}}$ \\
Vernonia amygdalina & $66.86 \pm 4.05^{\mathrm{a}}$ \\
Rutin & $157.72 \pm 7.38^{\mathrm{b}}$ \\
\hline
\end{tabular}

Note: “-": $>1024 \mu \mathrm{g} / \mathrm{ml} ; \mathrm{RSa}_{50}$ : concentration of tested sample necessary to decrease by $50 \%$ the free radical NO. Values bearing the different superscript letters are significantly different $(p<0.05)$.

TABLE 7: Correlation between different antioxidant activity and antibacterial parameters of the methanol extracts of thirteen antibacterial edible plants.

Note: values in parentheses are $p$ values. ${ }^{* *}$ Significant correlation with probability threshold $0.01 . *$ Significant correlation with probability threshold 0.05 .

extracts possess higher activity than that obtained $(11.39 \mathrm{mg} / \mathrm{ml})$ with the methanol extract by sheets which $S$. edule still presented one of the most reducing powers against $\mathrm{DPPH}^{\circ}[38]$.
In addition to phenols and other phytochemicals (alkaloids, steroids, and saponins) highlighted in this work, the antioxidant activities of $M$. esculenta could also be explained by its high anthocyanins and vitamin C [43]. Indeed, it has also highlighted antiradical activities (against $\mathrm{DPPH}^{\circ}$ and 
superoxide radical) of methanol extracts and acetone from the said plant and their metal chelator and antioxidant against deoxyribose degradation effect. All these activities only expressed in percentages were variable depending on the test sample and in particular with a reduction percentage of $\mathrm{DPPH}^{\circ}$ of $15.2 \%$ with $0.1 \mathrm{mM}$ methanolic extract [43].

The methanol extract of $S$. nigrum has already made radical scavenging activity against $\mathrm{DPPH}^{\circ}$ up to $92 \%$ (a much lower activity with the aqueous extract) with a correlation with its phenolic content. Isolated from this plant glycoproteins could also justify highlighted in this study activity because they exert concentration-dependent antiradical activity against $\mathrm{DPPH}^{\circ}$ and superoxide anion, as well as activity against the oxidation of 2-deoxyribose [108].

It has been shown that three flavones (luteolin, luteolin 7-O- $\beta$-glucuronide, and luteolin $7-\mathrm{O}-\beta$-glucoside) isolated from $V$. amygdalina have protective effects against the oxidation of $\beta$-carotene and oleic acid, lutein being more active than BHT [109]. It was also shown that three daily administrations of the aqueous extract of the plant at doses of 50 and $100 \mathrm{mg} / \mathrm{kg}$ can prevent the induction (acetaminophen) in oxidative stress and lipid peroxidation in rats [110].

Several parameters must be considered to maximize the biological effects of different vegetables, fruits, and spices of this study.

The oxidation is an essential biological process for the production of energy in many living organisms. However, certain pathological conditions such as microbial attacks cause an excessive production of reactive oxygen species (ROS) [111]. This excess of ROS in turn can cause many physiological disorders [112].

The extract of $P$. nigrum has both the highest antimicrobial activity and the highest antioxidant activity. Although the correlation between antioxidant and antibacterial activity is difficult to establish with other plant extracts of this study, the combination of these two activities observed in all these could be of great importance in the treatment of infectious diseases, as in addition to the elimination of the causative agent or the inhibition of growth, they may inhibit the oxidative processes that often aggravate the symptoms of these diseases.

Different plant extracts studied in this work showed antiradical activity against $\mathrm{DPPH}$ radicals and $\mathrm{NO}^{\circ}$. The antiradical force varies greatly between antioxidants and radical to another. According to the proposed scale [113], antioxidants activities are considered significant or high if the $\mathrm{IC}_{50}<50 \mathrm{mg} / \mathrm{ml}$, moderate if $50 \mathrm{mg} / \mathrm{ml}<\mathrm{IC}_{50}<100 \mathrm{mcg} / \mathrm{ml}$, and low if $\mathrm{IC}_{50}>100 \mathrm{mcg} / \mathrm{ml}$. According to this scale, extracts of $P$. nigrum, S. edule, M. esculenta, L. capensis, V. amygdalina, $V$. hymenolepis, A. cruentus, T. occidentalis, and S. nigrum can be classified as extracts with high activity against $\mathrm{DPPH}^{\circ}$ free radical scavenging activity and extract of $T$. triangulare can be classified as extract with moderate scavenging activity against this radical. According to the same scale, although significant differences were not observed between the activity of many extracts ( $M$. esculenta, L. capensis V. hymenolepis C. melo, S. nigrum A. hybridus, T. occidentalis, and V. amygdalina) and that of rutin (reference), only extracts of $M$. esculenta presented high activity against the $\mathrm{NO}^{\circ}$ free radical, while moderate activities were observed with extracts of $S$. edule and $V$. hymenolepis using the same scale [113].

The radical scavenging activity of chemical compounds against DPPH radical is related to their ability to provide electrons and/or protons. Sodium nitroprusside, at physiological $\mathrm{pH}$, decomposes in solution by producing $\mathrm{NO}^{\circ}$ radical. In the presence of oxygen, radical leads to the formation of nitrite from nitrate. The chromogen formed during diazotization with nitrite ions with Griess reagent has a maximum absorbance at a wavelength of $546 \mathrm{~nm}$ [100]. By complexing with the $\mathrm{NO}^{\circ}$ radical, compounds contained in extracts of plants thus inhibited the formation of the chromogen.

The elevated reducing powers of plant extracts of this study could be explained by high levels of total phenolics and flavonoids [114]. Reducing power is very often linked to the effect of the compounds that are electron donors [115]. The extract of $P$. nigrum would be the richest in reductones extracted followed by extracts T. triangulare, A. hybridus, M. esculenta, and V. amygdalina.

As demonstrated with the strong correlation between the phenol content and total reducing power, the action of phenols partly explains the reducing power and antiradical activity against DPPH plant extracts. The presence of phenols in all extracts is not a surprising fact, since they are present in all vascular plants [116]. Phenolic compounds from plants are powerful antioxidants capable of preventing oxidative damage to biomolecules such as DNA, lipids, and proteins that play a role in chronic diseases such as cancer and cardiovascular diseases $[117,118]$. It has also been shown that there is a linear relationship between the antioxidant power plant and the concentration of phenolic compounds [56] acting through their hydroxyl groups [119].

The subset of the most abundant polyphenols in our diet, flavonoids are known primarily for their antioxidant activity $[119,120]$. They are a group of phenols particularly clever and quick to transfer an electron. This electron stabilizing free radicals explains the scavenging activity of various flavonoids. However, no significant correlation between total phenolic content and flavonoid content could explain the lack of a significant correlation between reducing power and total flavonoid content, which also presented a negative correlation with NO.

\section{Conclusion}

This study was aimed at evaluating the antioxidant activity of thirteen Cameroonian plants which previously displayed antibacterial activities. The thirteen plant extracts exhibited high antioxidant activities correlated to their reducing power. They possess total reducing powers (from 2.41 to $27.81 \mu \mathrm{g}$ ascorbic acid equivalents/g of dried extract), total phenol contents ( 2.65 and $35.03 \mathrm{mg}$ of gallic acid equivalents/g of dried extract), total flavonoid contents ( 0.15 and $5.99 \mu \mathrm{g}$ of rutin equivalents/g of dried extract), and free radical scavenging power against DPPH (IC50 varying between 1.65 and $375.43 \mu \mathrm{g} / \mathrm{ml}$ ) and NO (IC50 varying from 19.77 to $157.72 \mu \mathrm{g} / \mathrm{ml})$. Statistically insignificant positive correlations $(p>0.5)$ exist between the antibacterial 
activities of these plants and the antioxidant activities with the strongest correlations observed between antibacterial activities and total phenols content, followed by free radical scavenging activity against nitric oxide. These important antioxidant activities demonstrated in the present study provide enough evidence to support the fact that the thirteen Cameroonian antibacterial plants can be used as a source of natural antioxidants and help combat oxidative stress which is sometimes associated with infectious conditions.

\section{Data Availability}

The experimental data used to support the findings of this study are included within the article.

\section{Conflicts of Interest}

The authors declare that they have no conflicts of interest.

\section{Authors' Contributions}

DED VK, JAKN, JRK, and MM designed the experiments, carried out the study, and wrote the manuscript; all authors read and approved the final manuscript.

\section{Acknowledgments}

The authors are thankful to The Agence Universitaire de la Francophonie and the Government of Romania for travel grants won by JAKN.

\section{Supplementary Materials}

Table S1: bacterial strains and features. Table S2: antibacterial activities/minimal inhibitory concentrations $(\mu \mathrm{g} / \mathrm{ml})$ of methanol extracts from the thirteen studied plants and chloramphenicol. (Supplementary Materials)

\section{References}

[1] M. D. Bagatini, J. A. S. Jaques, C. Santos de Oliveira et al., "Oxidative stress: noxious but also vital," in Novel Prospects in Oxidative and Nitrosative Stress, P. Atukeren, Ed., IntechOpen, London, UK, 2018.

[2] A. V. Ivanov, B. Bartosch, and M. G. Isaguliants, "Oxidative stress in infection and consequent disease," Oxidative Medicine and Cellular Longevity, vol. 2017, Article ID 3496043, 3 pages, 2017.

[3] D.-P. Xu, Y. Li, X. Meng et al., "Natural antioxidants in foods and medicinal plants: extraction, assessment and resources," International Journal of Molecular Sciences, vol. 18, no. 1, p. 96, 2017.

[4] J. A. K. Noumedem, M. Mihasan, S. T. Lacmata, M. Stefan, J. R. Kuiate, and V. Kuete, "Antibacterial activities of the methanol extracts of ten Cameroonian vegetables against Gram-negative multidrug-resistant bacteria," BMC Complementary and Alternative Medicine, vol. 13, p. 26, 2013.

[5] J. A. Noumedem, M. Mihasan, J. R. Kuiate et al., "In vitro antibacterial and antibiotic-potentiation activities of four edible plants against multidrug-resistant gram-negative species," BMC Complementary and Alternative Medicine, vol. 13, p. 190, 2013.
[6] Z. C. Maiyo, R. M. Ngure, J. C. Matasyoh, and R. Chepkorir, "Phytochemical constituents and antimicrobial activity of leaf extracts of three Amaranthus plant species," African Journal of Biotechnology, vol. 9, no. 21, pp. 3178-3182, 2010.

[7] H.-P. He, H. Corke, and J.-G. Cai, "Supercritical carbon dioxide extraction of oil and squalene from Amaranthus grain," Journal of Agricultural and Food Chemistry, vol. 51, no. 27, pp. 7921-7925, 2003.

[8] I. E. Akubugwo, N. A. Obasi, G. C. Chinyere, and A. E. Ugbogu, "Nutritional and chemical value of Amaranthus hybridus L. leaves from Afikpo, Nigeria," African Journal of Biotechnology, vol. 6, no. 24, pp. 2833-2839, 2007.

[9] I. E. Akubugwo, N. A. Obasi, G. C. Chinyere, and A. E. Ugbogu, "Mineral and phytochemical contents in leaves of Amaranthus hybridus L and Solanum nigrum L. subjected to different processing methods," African Journal of Biochemistry Research, vol. 2, no. 2, pp. 040-044, 2008.

[10] S. S. Dahiya, S. S. Sheoran, and S. K. Sharma, "Antibacterial activity of Amaranthus hybridus linn. root extracts," International Journal of Applied Biology and Pharmaceutical Technology, vol. 1, no. 1, pp. 46-49, 2010.

[11] M. Mwangi, "IeCAB2010: contribution of agriculture to achieving MDGs," in Contribution of Agricultural Sciences towards Achieving the Millenium Development Goalsp. 160, FaCT Publishing, Nairobi, Kenya, 2010.

[12] S. Rajwar, P. Khatri, R. Patel, S. Dwivedi, and A. Dwivedi, "An overview on potent herbal anticancer drugs," International Journal of Research in Pharmacy and Chemistry, vol. 1, no. 2, 2011.

[13] W. C. Hamisy, D. Mwaseba, I. E. Zilihona, and S. T. Mwihomeke, "Status and domestication potential of medicinal plants in the Uluguru mountain area, Tanzania", Wildlife Conservation Society of Tanzania (WCST), Morogoro, Tanzania, p. 55, 2000.

[14] R. E. Perdue, K. D. Carlson, and M. G. Gilbert, "Vernonia galamensis, potential new crop source of epoxy acid," Economic Botany, vol. 40, no. 1, pp. 54-68, 1986.

[15] R. J. Gilbert, Syntheses of Furanosesquiterpenoid Natural Products, University of Southampton, Southampton, UK, 1981.

[16] R.-Y. Yang, S. Lin, and G. Kuo, "Content and distribution of flavonoids among 91 edible plant species," Asia Pacific Journal of Clinical Nutrition, vol. 17, no. S1, pp. 275-279, 2008.

[17] A. F. Barrero, J. E. Oltra, A. Barragán, and M. Álvarez, "Approaches to the synthesis of 8-epi-vernolepin from germacrolide," Journal of the Chemical Society, Perkin Transactions 1, vol. 1, no. 24, pp. 4107-4114, 1998.

[18] S. Fane, Etude de la Toxicite de Certaines Plantes Vendues Sur Les Marches Du District de Bamako Doctorat D'état, Université de Bamako, Bamako, Mali, 2003.

[19] K. Bhanu Prasad, R. G. Avinash Kumar, M. J. Jyothi, A. Rasheed, and D. Dalith, "Natural antifilarial drugs: a review," International Journal of Pharmacology \& Toxicology, vol. 1, no. 1, pp. 1-10, 2011.

[20] E. Rodrigues, R. Tabach, J. C. F. GaldurÓz, and G. Negri, "Plants with possible anxiolytic and/or hypnotic effects indicated by three Brazilian cultures-Indians, Afro-Brazilians, and river-dwellers," Studies in Natural Products Chemistry, vol. 35, pp. 549-595, 2008.

[21] S. H. Katz and W. W. Weaver, Encyclopedia of Food and CultureSchribner, New York, NY, USA, 2003. 
[22] M. Sayyah, N. Hadidi, and M. Kamalinejad, "Analgesic and anti-inflammatory activity of Lactuca sativa seed extract in rats," Journal of Ethnopharmacology, vol. 92, no. 2-3, pp. 325-329, 2004.

[23] R. Cruz, P. Baptista, S. Cunha, J. A. Pereira, and S. Casal, "Carotenoids of lettuce (Lactuca sativa L.) grown on soil enriched with spent coffee grounds," Molecules, vol. 17, no. 2, pp. 1535-1547, 2012.

[24] T. A. Van Beek, P. Maas, B. M. King, E. Leclercq, A. G. J. Voragen, and A. De Groot, "Bitter sesquiterpene lactones from chicory roots," Journal of Agricultural and Food Chemistry, vol. 38, no. 4, pp. 1035-1038, 1990.

[25] G. Brandi, G. Amagliani, G. F. Schiavano, M. De Santi, and M. Sisti, "Activity of Brassica oleracea leaf juice on foodborne pathogenic bacteria," Journal of Food Protection, vol. 69, no. 9, pp. 2274-2279, 2006.

[26] M. H. Bennett, M. D. S. Gallagher, C. S. Bestwick, J. T. Rossiter, and J. W. Mansfield, "The phytoalexin response of lettuce to challenge by Botrytis cinerea, Bremia lactucae and Pseudomonas syringae pv. phaseolicola," Physiological and Molecular Plant Pathology, vol. 44, no. 5, pp. 321-333, 1994.

[27] X.-J. Ye, T.-B. Ng, Z.-J. Wu et al., "Protein from red cabbage (Brassica oleracea) seeds with antifungal, antibacterial, and anticancer activities," Journal of Agricultural and Food Chemistry, vol. 59, no. 18, pp. 10232-10238, 2011.

[28] L. F. Gonzalex, A. Valedon, and W. L. Stiehil, "Depressant pharmacological effects of component isolated from lettuce, Lactuca sativa," International Journal of Crude Drug Research, vol. 24, no. 3, p. 154, 1996.

[29] S. A. Sid, H. El-Kashef, M. M. Elmazar, and O. Slam, "Phytochemical and pharmacological studies on Lactuca sativa seed oil," Fitoterapia, vol. 67, no. 3, p. 215, 1996.

[30] R. R. Roman, S.-J. L. Flores, and A. F. J. Alarcon, "Antihyperglycaemic effect of some edible plants," Journal of Ethnophramacology, vol. 48, no. 1, p. 25, 1995.

[31] M. Garg, C. Garg, K. Mukherjee Pulok, and B. Suresh, "Antioxidant potential of Lactuca sativa," Ancient Science of Life, vol. 24, no. 1, pp. 1-4, 2004.

[32] R. B. Patil, S. R. Vora, and M. M. Pillai, "Antioxidant effect of plant extracts on phospholipids levels in oxidatively stressed male reproductive organs in mice," Iranian Journal of Reproductive Medicine, vol. 7, no. 1, pp. 35-39, 2009.

[33] S. N. Wambugu, P. M. Mathiu, D. W. Gakuya, T. I. Kanui, J. D. Kabasa, and S. G. Kiama, "Medicinal plants used in the management of chronic joint pains in Machakos and Makueni counties, Kenya," Journal of Ethnopharmacology, vol. 137, no. 2, pp. 945-955, 2011.

[34] K. Michalska, A. Stojakowska, J. Malarz, I. Doležalová, A. Lebeda, and W. Kisiel, "Systematic implications of sesquiterpene lactones in Lactuca species," Biochemical Systematics and Ecology, vol. 37, no. 3, pp. 174-179, 2009.

[35] K. S. Albone, P. Gaskin, J. MacMillan, and V. M. Sponsel, "Identification and localization of gibberellins in maturing seeds of the cucurbit Sechium edule, and a comparison between this cucurbit and the legume Phaseolus coccineus," Planta, vol. 162, no. 6, pp. 560-565, 1984.

[36] T. Siciliano, N. De Tommasi, I. Morelli, and A. Braca, "Study of flavonoids of Sechium edule (Jacq) swartz (cucurbitaceae) different edible organs by liquid chromatography photodiode array mass spectrometry," Journal of Agricultural and Food Chemistry, vol. 52, no. 21, pp. 6510-6515, 2004.

[37] K. Dhiman, A. Gupta, D. K. Sharma, N. S. Gill, and K. Goyal, "A review on the medicinal important plants of the family of
Cucurbitaceae," Asian Journal of Clinical Nutrition, vol. 4, no. 1, pp. 16-26, 2012.

[38] A. Ordonez, J. Gomez, M. Vattuone, and M. Lsla, "Antioxidant activities of Sechium edule (Jacq.) swartz extracts," Food Chemistry, vol. 97, no. 3, pp. 452-458, 2006.

[39] A. A. L. Ordoñez, J. D. Gomez, N. M. Cudmani, M. A. Vattuone, and M. I. Isla, "Antimicrobial activity of nine extracts of Sechium edule (Jacq.) Swartz," Microbial Ecology in Health and Disease, vol. 15, no. 1, 2003.

[40] E. A. Gordon, L. J. Guppy, and M. Nelson, "The antihypertensive effects of the Jamaican Cho-Cho (Sechium edule)," The West Indian Medicinal Journal, vol. 49, no. 1, pp. 27-31, 2000.

[41] S. M. Firdous, K. Sravanthi, R. Debnath, and K. Neeraja, "Protective effect of ethanolic extract and its ethylacetate and n-butanol fractions of Sechium edule fruits against paracetamol induced hepatic injury in mice," Asian Journal of Pharmaceutical and Clinical Research, vol. 5, no. 2, pp. 10-14, 2012.

[42] S. M. Abd Aziz, C. N. Low, L. C. Chai et al., "Screening of selected Malaysian plants against several food borne pathogen bacteria," International Food Research Journal, vol. 18, no. 3, pp. 1195-1201, 2011.

[43] R. Suresh, M. Saravanakumar, and P. Suganyadevi, “Anthocyanins from indian cassava (Manihot esculenta crantz) and its antioxidant properties," International Food Research Journal, vol. 18, no. 3, pp. 1195-1201, 2011.

[44] Z. A. Zakaria, M. K. Hussain, M. N. Somchit et al., "The in vitro antibacterial activity and brine shrimp toxicity of Manihot esculenta var. Sri pontian (euphorbiacea) extracts," International Journal of Pharmacology, vol. 2, no. 2, pp. 216-220, 2006.

[45] S. Sarkar and D. Buha, "Effect of ripe fruit pulp extract of Cucurbita pepo Linn. in aspirin induced gastric and duodenal ulcer in rats," Indian Journal of Experimental Biology, vol. 46, no. 9, pp. 639-645, 2008.

[46] T. Karpagam, B. Varalakshmi, J. S. Bai, and S. Gomathi, "Effect of different doses of Cucurbita pepo linn extract as an anti-Inflammatory and analgesic nutraceautical agent on inflamed rats," International Journal of Pharmaceutical Research and Development, vol. 3, no. 3, pp. 184-192, 2011.

[47] B.-E. Carbin, B. Larsson, and O. Lindahl, "Treatment of benign prostatic hyperplasia with phytosterols," British Journal of Urology, vol. 66, no. 6, pp. 639-641, 1990.

[48] B. E. Carbin and R. Eliasson, "Treatment by curbicin in benign prostatic hyperplasia (BPH)," Swedish Journal of Biological Medicine, vol. 2, pp. 7-9, 1989.

[49] H. Al-Zuhair, A. A. Abd el-Fattah, and H. A. Abd el Latif, "Efficacy of simvastatin and pumpkin-seed oil in the management of dietary-induced hypercholesterolemia," Pharmacological Research, vol. 35, no. 5, pp. 403-408, 1997.

[50] C. Z. Nkosi, A. R. Opoku, and S. E. Terblanche, "Effect of pumpkin seed (cucurbita pepo) protein isolate on the activity levels of certain plasma enzymes in CCl4-induced liver injury in low-protein fed rats," Phytotherapy Research, vol. 19, no. 4, pp. 341-345, 2005.

[51] L. D. Sharma, H. S. Bagha, and P. S. Srivastava, "In vitro anthelmintic screening of indigenous medicinal plants against Haemonchus contortus (Rudolphi, 1803) Cobbold, 1898 of sheep and goats," Indian Journal of Animal Rescources, vol. 5, pp. 33-38, 1971.

[52] G. K. A. Adepoju and A. A. Adebanj, "Effect of consumption of Cucurbita pepo seeds on haematological and biochemical 
parameters," African Journal of Pharmacy and Pharmacology, vol. 5, no. 1, pp. 18-22, 2011.

[53] R. Jain, A. Sharma, S. Gupta, I. P. Sarethy, and R. Gabrani, "Solanum nigrum: current perspectives on therapeutic properties," Alternative Medicine Review, vol. 16, no. 1, pp. 78-85, 2011.

[54] J. M. Calderón-Montaño, E. Burgos-Morón, C. PérezGuerrero, and M. López-Lázaro, "A review on the dietary flavonoid kaempferol," Mini-Reviews in Medicinal Chemistry, vol. 11, no. 4, pp. 298-344, 2011.

[55] C. Marie-Magdeleine, L. Udino, L. Philibert, B. Bocage, and H. Archimede, "In vitro effects of Cassava (Manihot esculenta) leaf extracts on four development stages of Haemonchus contortus," Veterinary Parasitology, vol. 173, no. 12, pp. 85-92, 2010.

[56] X.-F. Cai, Y.-W. Chin, S.-R. Oh, O.-K. Kwon, K.-S. Ahn, and H.-K. Lee, "Anti-inflammatory constituents from Solanum nigru," Bulletin of the Korean Chemical Society, vol. 31, no. 1, pp. 199-201, 2010.

[57] A. Rawani, A. Ghosh, and G. Chandra, "Mosquito larvicidal activities of Solanum nigrum L. leaf extract against Culex quinquefasciatus say," Parasitology Research, vol. 107, no. 5, pp. 1235-1240, 2010.

[58] S. Kumar, G. D. Bagchi, and M. P. Darokar, "Antibacterial activity observed in the seeds of some Coprophilous plants," International Journal of Pharmacognosy, vol. 35, no. 3, pp. 179-184, 1997.

[59] N. Ahmad, H. Fazal, B. H. Abbasi, S. Farooq, M. Ali, and M. A. Khan, "Biological role of Piper nigrum L. (Black pepper): a revie," Asian Pacific Journal of Tropical Biomedicine, vol. 2, no. 3, pp. 1-10, 2012.

[60] A. N. Menon, K. P. Padmakumari, and A. Jayalekshmy, "Essential oil composition of four major cultivars of black pepper (Piper nigrum L.) III," Journal of Essential Oil Research, vol. 15, no. 3, pp. 155-157, 2003.

[61] M. J. Kang, J. Y. Cho, B. H. Shim, D. K. Kim, and J. Lee, "Bioavailability enhancing activities of natural compounds from medicinal plants," Journal of Medicinal Plants Research, vol. 3, no. 13, pp. 1204-1211, 2009.

[62] G. C. L. Ee, C. M. Lim, M. Rahmani, K. Shaari, and C. F. J. Bong, "Pellitorine, a potential anti-cancer lead compound against HL60 and MCT-7 cell lines and microbial transformation of piperine from Piper nigrum," Molecules, vol. 15, no. 4, pp. 2398-2404, 2010.

[63] R. S. Vijayakumar, D. Surya, and N. Nalini, "Antioxidant efficacy of black pepper (Piper nigrum L.) and piperine in rats with high fat diet induced oxidative stress," Redox Report, vol. 9, no. 2, pp. 105-110, 2004.

[64] J. Neha and R. Misha, "Antioxidant activity of trikatu mega ext," International Journal of Research in Pharmaceutical and Biomedical Sciences, vol. 2, no. 2, pp. 624-628, 2011.

[65] O. Erturk, "Antibacterial and antifungal activity of ethanolic extracts from eleven spice plants," Biologia Brastislava, vol. 61, no. 3, pp. 275-278, 2006.

[66] S. Li, C. Wang, W. Li, K. Koike, T. Nikaido, and M.-W. Wang, "Antidepressant-like effects of Piperine and its derivative, antiepilepsirine," Journal of Asian Natural Products Research, vol. 9, no. 5, pp. 421-430, 2007.

[67] A. Umit, I. Kadir, and K. O. Akgun, "Antifungal activity of aqueous extracts of spices against bean rust (Uromyces appendiculatus)," Allelopathy Journal, vol. 24, no. 1, pp. 0973-5046, 2009.
[68] V. S. Parmar, M. E. Bracke, J. Philippe et al., "Anti-invasive activity of alkaloids and polyphenolics in vitro," Bioorganic \& Medicinal Chemistry, vol. 5, no. 8, pp. 1609-1619, 1997.

[69] S. Kumar, V. Singhal, R. Roshan, A. Sharma, G. W. Rembhotkar, and B. Ghosh, "Piperine inhibits TNF- $\alpha$ induced adhesion of neutrophils to endothelial monolayer through suppression of NF- $\kappa \mathrm{B}$ and I $\kappa \mathrm{B}$ kinase activation," European Journal of Pharmacology, vol. 575, no. 1-3, pp. 177-186, 2007.

[70] N. Pathak and S. Khandelwal, "Cytoprotective and immunomodulating properties of piperine on murine splenocytes: an in vitro study," European Journal of Pharmacology, vol. 576, no. 1-3, pp. 160-170, 2007.

[71] E. S. Sunila and G. Kuttan, "Immunomodulatory and antitumor activity of Piper longum Linn. and piperine," Journal of Ethnopharmacology, vol. 90, no. 2-3, pp. 339-346, 2004.

[72] R. K. Upadhyay and G. Jaiswal, "Evaluation of biological activities of Piper nigrum oil against Tribolium castaneum," Bulletin of Insectology, vol. 60, pp. 57-61, 2007.

[73] B. A. Iwalokun, S. B. Bamiro, and O. O. Durojaiye, "An antimicrobial evaluation of Vernonia amygdalina (compositae) against gram-positive and gram-negative bacteria from Lagos, Nigeria," West African Journal of Pharmacology and Drug Research, vol. 19, no. 1, pp. 9-15, 2003.

[74] C. I. Uzoigwe and O. K. Agwa, "Antimicrobial activity of Vernonia amygdalina on selected urinary tract pathogens," African Journal of Microbiology Research, vol. 5, no. 12, pp. 1467-1472, 2011.

[75] D. A. Akinpelu, "Antimicrobial activity of Vernonia amygdalina leaves," Fitoterapia, vol. 70, no. 4, pp. 432-434, 1999.

[76] H. U. Nwanjo and E. A. Nwokoro, "Antidiabetic and biochemical effects of aqueous extract of Vernonia amygdalina leaf in normoglycaemic and and diabetic rats," Journal of Life Science Innovations, vol. 7, pp. 6-10, 2004.

[77] S. M. Kupchan, R. J. Hemingway, A. Karim, and D. Werner, "Tumor inhibitors. XLVII. Vernodalin and vernomygdin, two new cytotoxic sesquiterpene lactones from Vernonia amygdalina Del," The Journal of Organic Chemistry, vol. 34, no. $12,1969$.

[78] E. B. Izevbigie, "Discovery of water-soluble anticancer agents (edotides) from a vegetable found in Benin city, Nigeria," Experimental Biology and Medicine, vol. 228, no. 3, pp. 293-298, 2003.

[79] A. Tadesse, A. Gebre-Hiwot, K. Asres, M. Djote, and D. Frommel, "The in-vitro activity of Vernonia amygdalina on Leishmania acthiopica," Ethiopian Medical Journal, vol. 31, no. 3, pp. 183-189, 1993.

[80] T. O. Fasola, P. C. Okeocha, and A. Odetola, "Screening for hypoglycaemic potential of Vernonia amygdalina," Ethnobotanical Leaflet, vol. 14, pp. 759-765, 2010.

[81] H. U. Nwanjo, "Efficacy of aqueous leaf extract of Vernonia amygdalina on plasma lipoprotein and oxidative status in diabetic rat models," Nigerian Journal of Physiological Science, vol. 20, no. 1-2, pp. 39-42, 2005.

[82] O. A. Eseyin, P. Ebong, A. Ekpo, A. Igboasoiyi, and E. Oforah, "Hypoglycemic effect of the seed extract of Telfairia occidentalis in rat," Pakistan Journal of Biological Sciences: PJBS, vol. 10, no. 3, pp. 498-501, 2007.

[83] G. Oboh, E. E. Nwanna, and C. A. Elusiyan, "Antioxidant and antimicrobial properties of Telfairia occidentalis (fluted pumpkin) leaf extracts," Journal of Pharmacology and Toxicology, vol. 1, no. 2, pp. 167-175, 2006.

[84] A. A. A. Kayode, O. T. Kayode, and A. A. Odetola, "Telfairia occidentalis ameliorates oxidative brain damage in 
malnorished rats," International Journal of Biological Chemistry, vol. 4, no. 1, pp. 10-18, 2010.

[85] M. A. Sonibare and R. B. Abegunde, "Ethnobotanical study of medicinal plants used by the Laniba village people in south western Nigeria," African Journal of Pharmacy and Pharmacology, vol. 6, no. 24, pp. 1726-1732, 2012.

[86] A. Ekpo, O. Eseyin, N. Kalu, O. Jackson, and E. J. Edoho, "Studies on the biochemical effects of Talinum triangulare in rat," Journal of Pharmacology and Toxicology, vol. 2, no. 3, pp. 300-303, 2007.

[87] C. Adewunmi and E. Sofowora, "Preliminary screening of some plant extracts for molluscicidal activity," Planta Medica, vol. 39, no. 5, pp. 57-65, 1980.

[88] R. Sridhar and G. Lakshminarayana, "Lipid classes, fatty acids, and tocopherols of leaves of six edible plant species," Journal of Agricultural and Food Chemistry, vol. 41, no. 1, pp. 61-63, 1993.

[89] P. M. Aja, A. N. C. Okaka, P. N. Onu, U. Ibiam, and A. J. Urako, "Phytochemical composition of Talinum triangulare (water leaf) leaves," Pakistan Journal of Nutrition, vol. 9, no. 6, pp. 527-530, 2010.

[90] M. O. Ezekwe, S. A. Besong, and P. E. Igbokwe, "Beneficial influence of purslane and waterleaf supplement to human," FASEB Journal, vol. 16, p. A639, 2001.

[91] L. Váli, H. Fébel, É. Stefanovits-Bányai et al., "Duodenum protecting effects of table beet (Beta vulgaris L. ssp. esculenta var. rubra) during hepatic ischaemia-reperfusion," Acta Alimentaria, vol. 35, no. 4, pp. 445-453, 2006.

[92] D. A. Ofusori, A. E. Adelakun, A. O. Ayoka et al., "Waterleaf (Talinum triangulare) enhances cerebral functions in Swiss albino mice," Journal of Neurological Sciences (Turkish), vol. 25, no. 4, pp. 239-246, 2008.

[93] E. O. Iwalewa, C. O. Adewunmi, N. O. A. Omisore et al., "Pro- and antioxidant effects and cytoprotective potentials of nine edible vegetables in southwest Nigeria," Journal of Medicinal Food, vol. 8, no. 4, pp. 539-544, 2005.

[94] E. S. Oluwole, A. O. Falade, and O. O. Ogundipe, "Antiinflammatory effect of some common Nigerian vegetables," Nigerian Journal of Physiological Sciences, vol. 18, pp. 35-38, 2003.

[95] U. F. Udo, E. T. Ifon, I. B. Umoh, and O. U. Eka, "In vivo evaluation of iron bioavalability in some Nigerian peasant meals by haemoglobin regeneration technique," Central African Journal of Medicine, vol. 39, no. 7, pp. 142-146, 1993.

[96] P. Pasko, H. Barton, P. Zagrodzki, S. Gorinstein, M. Fołta, and M. Zachwieja, "Anthocyanins, total polyphenols and antioxidant activity in amaranth and quinoa seeds and sprouts during their growth," Food Chemistry, vol. 115, no. 3, pp. 994-998, 2009.

[97] N. M. Guliev, G. G. Babaev, S. M. Bairamov, and D. A. Aliev, "Purification, properties, and localization of two carbonic anhydrases from Amaranthus cruentus leaves," Russian Journal of Plant Physiology, vol. 50, no. 2, pp. 213-219, 2003.

[98] V. L. Singleton and J. A. Rossi, "Colorimetry of total phenolics with phosphomolybdic-phosphotungstic acid reagents," American Journal of Enology and Viticulture, vol. 16, no. 3, pp. 144-158, 1965.

[99] L. L. Mensor, F. S. Menezes, G. G. Leitão et al., "Screening of Brazilian plant extracts for antioxidant activity by the use of DPPH free radical method," Phytotherapy Research, vol. 15, no. 2, pp. 127-130, 2001.

[100] C. D. Shajiselvin and A. K. Mutu, "In vitro free radical scavenging activity of various extracts of whole plant of
Borreria hispida L." Achives of Applied Science Research, vol. 2, no. 2, pp. 54-60, 2010.

[101] S. Gorinstein, A. Lojek, A. Číž et al., "Comparison of composition and antioxidant capacity of some cereals and pseudocereals," International Journal of Food Science and Technology, vol. 43, no. 4, pp. 629-637, 2008.

[102] P. Paśko, H. Bartoń, P. Zagrodzki et al., "Effect of amaranth seeds in diet on oxidative status in plasma and selected tissues of high fructose-fed rats," Food Chemistry, vol. 126, no. 1, pp. 85-90, 2011.

[103] J. M. Čanadanović-Brunet, S. S. Savatović, G. S. Ćetković et al., "Antioxidant and antimicrobial activities of beet root pomace extracts," Czech Journal of Food Sciences, vol. 29, no. 6 , pp. 575-585, 2011.

[104] V. L. Babu and R. Gowri, "Evaluation of antioxidant activity of Beta vulgaris root extract in rats," Asian Journal of Chemistry, vol. 22, no. 5, pp. 3385-3389, 2010.

[105] H. I. Ismail, K. W. Chan, A. A. Mariod, and M. Ismail, "Phenolic content and antioxidant activity of cantaloupe (Cucumis melo) methanolic extracts," Food Chemistry, vol. 119, no. 2, pp. 643-647, 2010.

[106] I. Vouldoukis, D. Lacan, C. Kamate et al., "Antioxidant and anti-inflammatory properties of a Cucumis melo LC. extract rich in superoxide dismutase activity," Journal of Ethnopharmacology, vol. 94, no. 1, pp. 67-75, 2004.

[107] F. M. Oloyede, I. O. Obisesan, G. O. Agbaje, and E. M. Obuotor, "Effect of NPK fertilizer on chemical composition of pumpkin (Cucurbita pepo Linn.) seeds," The Scientific World Journalfic World Journal, vol. 2012, Article ID 808196, 6 pages, 2012.

[108] S.-J. Lee and K.-T. Lim, "Antioxidative effects of glycoprotein isolated from Solanum nigrum Linne on oxygen radicals and its cytotoxic effects on the MCF-7 cell," Journal of Food Science, vol. 68, no. 2, pp. 466-470, 2003.

[109] G. O. Igile, W. Oleszek, M. Jurzysta, S. Burda, M. Fafunso, and A. A. Fasanmade, "Flavonoids from Vernonia amygdalina and their antioxidant activities," Journal of Agricultural and Food Chemistry, vol. 42, no. 11, pp. 2445-2448, 1994.

[110] B. A. Iwalokun, B. U. Efedede, J. A. Alabi-Sofunde, T. Oduala, O. A. Magbagbeola, and A. I. Akinwande, "Hepatoprotective and antioxidant activities of Vernonia amygdalinaon acetaminophen-induced hepatic damage in mice," Journal of Medicinal Food, vol. 9, no. 4, pp. 524-530, 2006.

[111] O. Blokina, E. Virolainen, and K. Fagerstedt, "Antioxidants, oxidative damage and oxygen deprivation stress: a review," Annals of Botany, vol. 91, no. 2, pp. 179-194, 2003.

[112] J. Moskovitz, S. Bar-Noy, W. M. Williams, J. Requena, B. S. Berlett, and E. R. Stadtman, "Methionine sulfoxide reductase (MsrA) is a regulator of antioxidant defense and lifespan in mammals," Proceedings of the National Academy of Sciences, vol. 98, no. 23, p. 12920, 2001.

[113] V. Kuete and T. Efferth, "Cameroonian medicinal plants: pharmacology and derived natural products," Frontiers in Pharmacology, vol. 1, p. 123, 2010.

[114] Y. El Atki, I. Aouam, F. El kamari et al., "Total phenolic and flavonoid contents and antioxidant activities of extracts from Teucrium polium growing wild in Morocco," Materials Today: Proceedings, vol. 13, pp. 777-783, 2019.

[115] N. Loganayaki, P. Siddhuraju, and S. Manian, "Antioxidant activity and free radical scavenging capacity of phenolic extracts from Helicteres isora L. and Ceiba pentandra L." 
Journal of Food Science and Technology, vol. 50, no. 4, pp. 687-695, 2013.

[116] M. Boutour, "Protection contre le stress photo oxydant chez des feuilles d'érable argenté (Acer saccharinum L.) grâce à l'oxydation de composés phénoliques caractérisée par voltammétrie cyclique," Québec Université du Québec, Trois Rivières, Canada, 2011.

[117] R. Randhir, Y. T. Lin, and K. Shetty, "Phenolics, their antioxidant and antimicrobial activity in dark germinated fenugreek sprouts in response to peptide and phytochemical elicitors," Asia Pacific Journal of Clinical Nutrition, vol. 13, no. 3, pp. 295-307, 2004.

[118] D. M. Kasote, "Flaxseed phenolics as natural antioxidants," International Food Research Journal, vol. 20, no. 1, pp. 27-34, 2013.

[119] H. Yamasaki, Y. Sakihama, and N. Ikehara, "Flavonoidperoxidase reaction as a detoxification mechanism of plant cells against $\mathrm{H}_{2} \mathrm{O}_{2}$," Plant Physiology, vol. 115, no. 4, pp. 1405-1412, 1997.

[120] A. Crozier, I. B. Jaganath, and M. N. Clifford, "Dietary phenolics: chemistry, bioavailability and effects on health," Natural Product Reports, vol. 26, no. 8, pp. 1001-1043, 2009. 